\title{
UM OLHAR SOMBRIO DA JUSTIÇA ESTADUAL CRIMINAL EM MARINGÁ, NO PARANÁ: \\ O USO (IN)DEVIDO DA MEDIDA CAUTELAR RESTRITIVA DA LIBERDADE HUMANA
}

\author{
A SHADY LOOK IN THE STATE CRIMINAL COURTS IN MARINGA, PARANA: \\ THE (UN)DUE USE OF THE RESTRICTIVE PREVENTIVE MEASURE OF HUMAN \\ FREEDOM
}

\begin{abstract}
Almir Santos Reis Júnior Doutor em Direito Penal pela Pontifícia Universidade Católica de São Paulo. Professor Adjunto de Direito Processual Penal na Universidade Estadual de Maringá, no Estado do Paraná, Brasil. almir.crime@gmail.com

(D) Gisele Mara de Oliveira Especialista em Ciências Penais pela Universidade Estadual de Maringá, Estado do Paraná. Membro da Comissão de Advogados Criminalistas da Ordem dos Advogados do Brasil, Subseção de Maringá. Advogada criminalista militante no Estado do Paraná, Brasil. giselem.oliveira@hotmail.com
\end{abstract}

Resumo: Este artigo apresenta um estudo sobre a decretação da prisão preventiva na Justiça Estadual em Maringá, no Paraná. A pesquisa foi desenvolvida com o escopo de compreender se decisões judiciais têm observado a natureza, a finalidade, os princípios e os fundamentos da prisão preventiva. Para tanto, coletouse e analisou-se todas as decisões judiciais proferidas no contexto do recebimento de autos de prisão em flagrante delito lavrados nos meses de janeiro e junho de 2018 e distribuídos à Central de Custódia em Maringá. Ao final, aplicando-se o método indutivo, a pesquisa evidenciou que a prisão preventiva não tem sido imposta com observância da natureza, da finalidade, dos princípios e dos fundamentos delineados no plano teórico.

Palavras-chave: Medida cautelar. Prisão preventiva. Processo penal.

Abstract: This paper exposes a study about the preventive detention in state courts in Maringa, Parana. The research was developed with the purpose of understanding if the judgments are in accordance with the nature, the purpose, the principles and the foundations of preventive detention. Therefore, all the judgments that were given about the proceedings of the eyewitness reports concerning a crime took down on January and on June of 2018 and distributed to the Central of Custody in Maringa were collected and analyzed. At last, applying the inductive method, the research made evident that the preventive detention has not been forced in conformity with the nature, the purpose, the principles and the foundations declared in theory.

Keywords: Preventive measure. Preventive detention. Criminal procedure.

REIS JÚNIOR, Almir Santos; OLIVEIRA, Gisele Mara de. Um olhar sombrio da justiça estadual criminal em Maringá, no Paraná: o uso (in)devido da medida cautelar restritiva da liberdade humana. Revista Thesis Juris - RTJ, São Paulo, v. 9, n. 1, p. 167-184, jan./jun. 2020. http://doi.org/10.5585/rtj.v9i1.16954. 
REIS JÚNIOR, Almir Santos; OLIVEIRA, Gisele Mara de. Um olhar sombrio da justiça estadual criminal em

\section{Introdução}

A prisão preventiva representa a privação da liberdade individual do investigado ou acusado, ainda durante o desenvolvimento da investigação criminal ou do processo penal por uma finalidade eminentemente processual. Ela tem como finalidade assegurar a investigação ou o processo, bem como a eficácia ou utilidade de uma sentença penal condenatória.

No plano teórico, diversos aspectos demarcam a prisão preventiva, entre os quais a natureza cautelar, a finalidade processual e a excepcionalidade, conforme previsto no art. 282, $\S 6^{\circ}$, do Código de Processo Penal.

Diante do expressivo número de presos provisórios no Brasil, propõe-se, por meio do presente trabalho, compreender se as razões que têm sido invocadas em decisões judiciais harmonizam-se com a natureza, a finalidade, os princípios e os fundamentos da medida delineados no plano teórico.

Para a construção do estudo, que compreendeu uma pesquisa de campo, coletou-se e analisou-se 320 (trezentos e vinte) decisões proferidas nos meses de janeiro e junho de 2018 pelos Juízes de Direito do Foro Central da Comarca da Região Metropolitana de Maringá, Estado do Paraná. Todas as decisões examinadas estão inseridas no contexto do recebimento de autos de prisão em flagrante delito, momento em que o juiz deve decidir pela decretação ou não da prisão preventiva, nos moldes do art. 310 do Código de Processo Penal, com nova redação conferida pela lei no 13.964/2019. Uma vez analisado e sistematizado o conteúdo de cada uma das decisões, aplicando-se o método indutivo, buscou-se compreender se a prisão preventiva tem sido imposta de acordo com a natureza, a finalidade, os princípios e os fundamentos estabelecidos no plano teórico.

\section{Da prisão preventiva e seus reflexos no sistema carcerário}

A prisão preventiva é uma medida cautelar do processo penal. É uma providência que possui finalidade processual. Representa a privação provisória da liberdade individual com vistas a afastar um risco concreto e efetivo de comprometimento da investigação ou do processo e, com isso, garantir o regular desenvolvimento do processo penal e a eficaz aplicação do poder de punir (FERNANDES, 2000; OLIVEIRA, 2017).

Por se tratar de medida privativa da liberdade individual antes do esgotamento do devido processo legal, a imposição da prisão preventiva se encontra cercada de princípios, requisitos e fundamentos, tudo para assegurar da maneira mais ampla possível a regra da liberdade de 
REIS JÚNIOR, Almir Santos; OLIVEIRA, Gisele Mara de. Um olhar sombrio da justiça estadual criminal em

locomoção durante o processo que deriva da presunção de inocência, enunciada na Constituição Federal de 1988 (GONÇALVES, 2011; LOPES JUNIOR, 2017).

A prisão preventiva é uma providência excepcional e instrumental. Sua decretação exige um perigo concreto e efetivo ao desenvolvimento da investigação ou do processo que não pode ser afastado por medidas cautelares alternativas, dispostas no art. 319, do Código de Processo Penal (GUSMAN, 2015; MENDONÇA, 2015).

Apenas a preservação da efetividade do processo por meio da eliminação ou minimização do perigo que decorre do estado de liberdade do investigado ou acusado (periculum libertatis) pode justificar a custódia penal de alguém presumidamente inocente (CAPEZ, 2015).

A decretação da prisão preventiva demanda também a existência de um juízo de probabilidade sobre a prática de um comportamento típico, ilícito e culpável atribuível ao investigado ou acusado (fumus comissi delicti) e também um prognóstico sobre a possível sanção penal aplicável, pois não deve ser mais gravosa do que a pena que se pode esperar em uma futura e eventual condenação (BADARÓ, 2008).

Apesar da instrumentalidade, da excepcionalidade e de todos os requisitos e princípios que a demarcam, o número expressivo de presos submetidos à prisão provisória no Brasil pode assinalar que a prisão preventiva não tem sido decretada com observância da natureza, da finalidade, dos princípios e dos fundamentos da medida.

Em 2015, 41\% (quarenta e um por cento) da população prisional no país estava submetida à prisão provisória, segundo o Levantamento Nacional de Informações Penitenciárias (INFOPEN) do Departamento Penitenciário Nacional, indicado na Resolução $\mathrm{n}^{\circ}$ 213 de 2015, do Conselho Nacional de Justiça (CNJ, 2019).

Em junho de 2016, no Brasil, havia 726.712 (setecentos e vinte e seis mil e setecentos e doze) pessoas privadas de liberdade. Dessa população, 40\% (quarenta por cento), ou seja, aproximadamente, 290.684 (duzentos e noventa mil e seiscentos e oitenta e quatro) pessoas se encontravam submetidas à prisão provisória. No Estado do Paraná, que concentrava 51.700 (cinquenta e um mil e setecentos) presos, 28,4\% (vinte e oito vírgula quatro por cento), isto é, 14.699 (quatorze mil e seiscentos e noventa e nove) estavam submetidos à prisão sem condenação (DEPEN, 2019).

Em junho de 2017, havia 726.354 (setecentos e vinte e seis mil, trezentos e cinquenta e quatro) pessoas privadas de liberdade no Brasil, das quais 235.241 (duzentos e trinta e cinco mil, duzentos e quarenta e um), ou seja, 32,39\% (trinta e dois vírgula trinta e nove por cento) eram presos sem condenação definitiva, segundo o Levantamento Nacional de Informações 
REIS JÚNIOR, Almir Santos; OLIVEIRA, Gisele Mara de. Um olhar sombrio da justiça estadual criminal em

Penitenciárias realizado pelo Departamento Penitenciário Nacional do Ministério da Justiça e Segurança Pública. No Paraná, a população prisional era de 50.029 (cinquenta mil e vinte nove) e, destes, 4.507 (quatro mil, quinhentos e sete), ou seja, 9,01\% (nove vírgula um por cento) eram presos provisórios (DEPEN, 2017).

Já em agosto de 2018, os registros das ordens de prisão decretadas pelas autoridades judiciárias vinculadas aos Tribunais de Justiça informaram que, no Brasil, havia 600.669 (seiscentos mil e seiscentos e sessenta e nove) pessoas privadas de liberdade e que 241.090 (duzentos e quarenta e um mil e noventa), isto é, 40,14\% (quarenta vírgula quatorze por cento) não possuíam condenação definitiva (CNJ, 2019).

Atualmente, no Brasil, há 247.582 (duzentos e quarenta e sete mil e quinhentos e oitenta e dois) presos provisórios, de uma população prisional de 717.810 (setecentos e dezessete mil e oitocentos e dez) pessoas. Ou seja, 34,49\% (trinta e quatro vírgula quarenta e nove por cento) das pessoas privadas de liberdade no Brasil estão submetidas à prisão sem condenação definitiva, conforme os dados disponibilizados pelo sistema Geopresídios do Conselho Nacional de Justiça e as informações apresentadas no relatório de inspeção nos estabelecimentos penais elaborado em 7 de junho de 2019 pelos juízos das varas de execução penal (CNJ, 2019).

Quanto ao Paraná, atualmente, 11.207 (onze mil e duzentos e sete), ou seja, 33,56\% (trinta e três vírgula cinquenta e seis por cento) dos presos são presos que não possuem condenação definitiva. Especificamente na cidade de Maringá, há 730 (setecentos e trinta) presos provisórios distribuídos no setor de carceragem da 9a Subdivisão Policial (9a SDP), na Colônia Penal Industrial de Maringá e na Casa de Custódia de Maringá (CNJ, 2019). Esses dados permitem concluir que, nos últimos 5 (cinco) anos, em média, os presos provisórios representam mais de $37 \%$ (trinta e sete por cento) da população prisional do país.

Disso, surge o inevitável questionamento: a prisão preventiva tem sido imposta com observância de seus requisitos legais, especialmente quanto à finalidade e a excepcionalidade que a demarcam?

Para esclarecer tal questão, coletou-se e analisou-se decisões judiciais proferidas pelos Juízes de Direito do Foro Central da Comarca da Região Metropolitana de Maringá, Estado do Paraná. 
REIS JÚNIOR, Almir Santos; OLIVEIRA, Gisele Mara de. Um olhar sombrio da justiça estadual criminal em

\section{Das decisões de juízes do Foro Central da Comarca da Região Metropolitana de Maringá quanto à prisão preventiva substitutiva da prisão em flagrante delito}

Para a coleta das decisões que compuseram a amostra de estudo, considerou-se o cenário processual em que o juiz deve decidir pela decretação ou não da prisão preventiva, nos termos do art. 310 do Código de Processo Penal, com nova redação conferida pela lei $\mathrm{n}^{\circ}$ 13.964, de 2019 .

Nos termos do art. 310 do Código de Processo Penal, ao receber um auto de prisão em flagrante delito, o juiz que reconhecer a sua legalidade deve enfrentar a necessidade de conversão da prisão em flagrante em preventiva, avaliar a possibilidade de concessão de liberdade provisória e examinar a necessidade de imposição de medida cautelar diversa da prisão. Contudo, a prisão preventiva não pode ser decretada de ofício. A imposição da medida, na fase preliminar do processo penal, deve apoiar-se na representação da autoridade policial ou no requerimento do Ministério Público, conforme normatiza o art. 311 do Código de Processo Penal.

Para facilitar o acesso dos pesquisadores ao acervo documental, preferiu-se as decisões exaradas no mesmo local de desenvolvimento do estudo. Optou-se, ainda, por selecionar as decisões do primeiro e do último mês do semestre que antecedeu ao início do trabalho, com a finalidade de reunir uma amostra quantitativamente significativa de recentes decisões.

No Foro Central da Comarca da Região Metropolitana de Maringá, Estado do Paraná, os autos de prisão em flagrante delito são distribuídos para a vara judicial que possui competência para realização de todas as audiências de custódia, denominada de Central de Custódia, nos termos da Resolução n $^{\circ}$ 93, de 12 de agosto de 2013, do Tribunal de Justiça do Estado do Paraná, com exceção dos casos em que ocorre o pagamento da fiança arbitrada pela autoridade policial e dos registrados durante o recesso forense. As decisões que compõem a amostra de estudo foram coletadas junto à referida vara judicial e, posteriormente, agrupadas conforme o provimento jurisdicional (decretação da prisão preventiva ou não decretação da prisão preventiva). Na sequência, o conteúdo de cada uma das decisões foi estudado, com a finalidade de se entender quais justificativas conduziram à decretação da prisão preventiva e quais razões afastaram a imposição da medida.

No Foro Central de Maringá, há sempre um juiz em gabinete, que primeiro decide, e um juiz da audiência de custódia, que reavalia a legalidade da prisão em flagrante e novamente delibera quanto à necessidade de imposição de uma medida cautelar. Por isso, o presente estudo compreendeu o exame tanto das decisões proferidas por um juiz em gabinete, como das exaradas nas respectivas audiências de custódia. 
REIS JÚNIOR, Almir Santos; OLIVEIRA, Gisele Mara de. Um olhar sombrio da justiça estadual criminal em

A amostra de decisões judiciais sobre a qual o estudo foi desenvolvido corresponde a 320 (trezentos e vinte) pronunciamentos de Juízes de Direito do Foro Central da Comarca da Região Metropolitana de Maringá, Estado do Paraná, no contexto do recebimento de autos de prisão em flagrante delito registrados e distribuídos nos meses de janeiro e junho de 2018.

Nos meses de janeiro e junho de 2018, a Central de Custódia do Foro Central de Maringá recebeu 197 (cento e noventa e sete) autos de prisão em flagrante delito. Dessas 197 (cento e noventa e sete) prisões em flagrante, 84 (oitenta e quatro) foram convertidas em prisão preventiva. 84 (oitenta e quatro), ou seja, $43 \%$ (quarenta e três por cento) dos autuados em flagrante delito permaneceram presos preventivamente após a audiência de custódia e 113 (cento e treze), isto é, $57 \%$ (cinquenta e sete por cento) receberam liberdade provisória.

Esses dados mostram-se relevantes, sobretudo, se comparados com as informações fornecidas pelo Conselho Nacional de Justiça de que, no período de 31 de julho de 2015 a 30 de junho de 2017 , apenas 44,68\% (quarenta e quatro vírgula sessenta e oito por cento) das audiências de custódia realizadas em todo o território nacional resultaram em concessão de liberdade provisória e, no mesmo período, no Estado do Paraná, 57,75\% (cinquenta e sete vírgula setenta e cinco por cento) resultaram na decretação de prisão preventiva e 42,25\% (quarenta e dois vírgula vinte e cinco por cento) na liberdade provisória do autuado (CNJ, 2019).

Das 320 (trezentos e vinte) decisões judiciais analisadas, 192 (cento e noventa e duas) importaram na conversão da prisão em flagrante delito em prisão preventiva, enquanto 128 (cento e vinte e oito) resultaram na concessão de liberdade provisória, o que representa, respectivamente, $60 \%$ (sessenta por cento) e $40 \%$ (quarenta por cento), conforme exposto no gráfico abaixo.

Gráfico 1 - Deliberações no recebimento de autos de prisão em flagrante delito

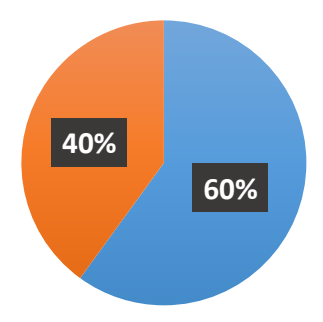

$$
\begin{aligned}
& \text { — Conversão em prisão preventiva } \\
& \text { — Concessão de liberdade provisória }
\end{aligned}
$$

Fonte: Os autores (2019). 
REIS JÚNIOR, Almir Santos; OLIVEIRA, Gisele Mara de. Um olhar sombrio da justiça estadual criminal em

Das decisões analisadas, a maioria importou prisão preventiva. Isso revela a inclinação dos julgadores a decidir pela privação da liberdade individual do autuado durante o processo, muito embora o princípio da presunção de inocência e a excepcionalidade da prisão, previstos no art. $5^{\circ}$, incisos LVII e LXVI, da Constituição Federal de 1988 e no art. 282, §6º , do Código de Processo Penal, conduzam à inafastável conclusão de que a regra consiste no estado de liberdade incondicionado e na manutenção dessa liberdade até eventual condenação definitiva à pena privativa de liberdade (GONÇALVES, 2011).

Desse quadro, pode-se depreender que as medidas cautelares que favorecem a liberdade individual sem prejudicar a instrução processual têm sido pouco utilizadas, preferindo-se a decretação da prisão preventiva quando outros instrumentos seriam suficientes e menos gravosos. Assim, conforme ensina Vasconcellos (2008), os princípios e direitos individuais fundamentais, tais como a presunção de inocência e a excepcionalidade da prisão, são colocados em segundo plano a fim de favorecer uma defesa do punitivismo, que não se adequa ao ordenamento jurídico brasileiro. Vê-se que a restrição da liberdade individual tem sido a regra durante o processo, e não sua valorização. As decisões examinadas já enunciam o emprego de um discurso jurídico repressivo em contraposição ao direito fundamental à liberdade de locomoção do indivíduo submetido à persecução penal. Ademais, representam uma significativa contribuição para o encarceramento antes mesmo de uma sentença condenatória definitiva.

\subsection{Das decisões de concessão de liberdade provisória}

A concessão de liberdade provisória com imposição de medida cautelar também exige uma situação de perigo decorrente do estado de liberdade do autuado, conforme o disposto no art. 282, inciso I, do Código de Processo Penal. Tanto a prisão preventiva, como as medidas acautelatórias alternativas são excepcionais e se justificam pela existência de um risco ao processo. Se inexistente o perigo, ou seja, a necessidade de imposição de uma medida assecuratória, deve-se conceder ao investigado a liberdade provisória sem qualquer restrição de direito. Além disso, as medidas cautelares diversas serão igualmente impostas com observância da natureza e do grau das exigências cautelares. Nenhuma restrição cautelarmente imposta pode afetar a liberdade individual mais do que o necessário para afastar o perigo ao processo, pois, em maior ou menor grau, as cautelares importam restrição a direito individual fundamental e constitucionalmente assegurado de alguém presumidamente inocente (BADARÓ, 2008). 
Nas decisões de concessão de liberdade provisória analisadas, constatou-se que em todos os 128 (cento e vinte e oito) pronunciamentos foram impostas medidas cautelares diversas da prisão. Em todos os casos, a liberdade provisória foi cumulada com medidas cautelares alternativas à prisão. Então, nos casos analisados, ou se decretou a prisão preventiva ou se impôs medida cautelar diversa da prisão. Com isso, supõe-se que em todos havia a necessidade de afastar um perigo atual, efetivo e concreto que justificasse a imposição de uma medida cautelar. No entanto, as decisões de concessão de liberdade provisória não revelaram os elementos fáticos que compunham a situação de perigo (periculum libertatis), legitimadora das medidas cautelares. Em apenas 3 (três) das 128 (cento e vinte e oito) decisões examinadas, houve indicação do que se considerou causa para aplicação das providências. Nesses casos, a necessidade de garantir a aplicação da lei penal e a conveniência da instrução criminal justificaram a aplicação das medidas assecuratórias. Contudo, nenhuma dessas decisões indicou um acontecimento que sugerisse o efetivo e concreto perigo à aplicação da lei penal ou à instrução do processo. As decisões apenas reportaram ao permissivo legal para imposição das medidas, sem evidenciarem a relação com o caso concreto, revelando, assim, ativismo judicial que pode configurar o crime de abuso de autoridade disposto no art. $9^{\circ}$ da lei $\mathrm{n}^{\circ}$ 13.869/2019, se comprovado o elemento subjetivo do tipo penal.

As medidas restritivas da liberdade individual foram impostas sem qualquer fundamentação idônea. Nesse aspecto, as decisões violaram o art. 93, inciso IX, da Constituição Federal de 1988. A decretação de medidas cautelares diversas, sem apreciação dos requisitos para decretação da custódia cautelar, tolheu, igualmente, o art. 319 do Código de Processo Penal. A imposição das medidas restritivas nos moldes das decisões estudadas significou também violação à presunção de inocência como princípio de tratamento, à excepcionalidade e à própria natureza cautelar das medidas alternativas, que são notas essenciais do sistema de medidas cautelares pessoais. Por isso, pode-se compreender que as providências impostas caracterizaram abusiva intervenção estatal na liberdade individual, o que, segundo Paiva (2014), é reflexo do punitivismo e do autoritarismo da resposta penal que demarcam o sistema de justiça criminal no país.

Avançando na análise das decisões de concessão de liberdade provisória, algumas das 128 (cento e vinte e oito) examinadas indicaram as razões pelas quais se concedia a liberdade provisória e não se impunha a prisão preventiva. Os argumentos invocados compreenderam: quantidade da pena máxima cominada ao delito imputado inferior a 4 (quatro) anos; possibilidade de cumprimento de eventual pena em regime inicial aberto; condições pessoais favoráveis, como residência estabelecida em endereço certo e fixo e ausência de antecedentes 
REIS JÚNIOR, Almir Santos; OLIVEIRA, Gisele Mara de. Um olhar sombrio da justiça estadual criminal em

criminais ou condenação definitiva pretérita; infração cometida sem emprego de violência ou grave ameaça à pessoa, sem emprego de arma de fogo ou de arma branca; recuperação do objeto material nos delitos patrimoniais; e ausência dos requisitos autorizadores da prisão preventiva previstos no art. 312 do Código de Processo Penal.

Esses argumentos são, basicamente, razões legais de afastamento da prisão preventiva. O art. 312 do Código de Processo Penal descreve os pressupostos e os fundamentos da prisão preventiva. O art. 313, inciso I, do Código de Processo Penal veda a imposição da prisão preventiva aos acusados de delito com pena privativa de liberdade cominada máxima inferior a 4 (quatro) anos. A existência de residência estabelecida em endereço certo e fixo sugere o desinteresse do acusado em se ausentar do domicílio da culpa e, por conseguinte, a inexistência de perigo ao regular andamento do processo. A ausência de antecedentes criminais ou condenação definitiva pretérita aponta para um possível envolvimento circunstancial do autuado com a prática delitiva e autoriza o abrandamento da pena, como previsto no art. 33, $\S 4^{\circ}$, da lei n ${ }^{\circ} 11.343 / 06$ para o tráfico de drogas, por exemplo, bem como a substituição da pena privativa de liberdade por restritiva de direitos, nos moldes do art. 44 do Código Penal. O cometimento de delito sem violência ou grave ameaça à pessoa, sem emprego de arma de fogo ou de arma branca e a recuperação do objeto material nos delitos patrimoniais estão também relacionadas com uma quantidade reduzida de pena, que, a princípio, autoriza o cumprimento de eventual pena em regime diferente do fechado, como previsto no art. $33, \S 2^{\circ}$, do Código Penal, bem como a substituição da pena privativa por restritiva de direitos, nos moldes do art. 44 do Código Penal, o que significaria que, nesses casos, eventual prisão preventiva seria muito mais gravosa do que a pena aplicável.

Considerando as razões invocadas, tem-se que a aplicação de medidas cautelares alternativas nos casos examinados foi um desdobramento ordinário da inadmissibilidade da prisão preventiva. Mesmo ausente elemento fático que indicasse concretamente uma situação de perigo motivadora de qualquer providência cautelar, o não cabimento da prisão preventiva conduziu automaticamente à imposição de medidas cautelares diversas. Tal postura decisória é ilegal, já que as providências cautelares diversas previstas essencialmente no art. 319 do Código de Processo Penal não constituem desdobramento lógico da impossibilidade de imposição da prisão preventiva, conforme destaca Rodrigo Capez (2015).

As medidas cautelares alternativas são preferíveis em relação à prisão preventiva. Por isso, diante da necessidade da tutela cautelar, deve-se realizar um juízo de adequação a partir da medida cautelar que representa menor afetação à liberdade individual até a prisão preventiva, a qual somente poderá ser decretada caso nenhuma das medidas de menor gravidade se mostrar 
REIS JÚNIOR, Almir Santos; OLIVEIRA, Gisele Mara de. Um olhar sombrio da justiça estadual criminal em

adequada e suficiente. Sem prejuízo dessa relação de preferência, a aplicação de qualquer medida cautelar exige fumus comissi delicti e periculum libertatis (LOPES JUNIOR, 2017). Todas as medidas cautelares, indistintamente, destinam-se a afastar uma situação de perigo, representada pelo periculum libertatis, e somente a presença desse risco extraordinário pode justificar o rompimento da inviolabilidade da liberdade individual, em maior ou menor grau, com a aplicação de uma providência cautelar (CAPEZ, 2015).

Ao contrário disso, nos casos examinados, as medidas cautelares alternativas foram impostas como consequência da inadmissibilidade da prisão preventiva, na ausência dos pressupostos e fundamentos exigidos. Sendo assim, as medidas cautelares diversas da prisão foram aplicadas em desrespeito à natureza, à finalidade, aos princípios e aos fundamentos delineados no campo teórico, mitigando, assim, sua natureza acautelatória, de modo que tais decisões não encontram amparo legal também nesse aspecto.

\subsection{Das decisões de conversão da prisão em flagrante em prisão preventiva}

Com relação aos fundamentos das decisões de conversão do flagrante em prisão preventiva, em 187 (cento e oitenta e sete) das 192 (cento e noventa e duas) decisões examinadas a garantia da ordem pública foi expressamente invocada. Em 102 (cento e dois) pronunciamentos, a garantia da ordem pública foi unicamente indicada como fundamento para imposição da medida. Em 78 (setenta e oito) das 187 (cento e oitenta e sete) decisões, a garantia da ordem pública foi invocada em conjunto com a garantia da aplicação da lei penal. Já em 5 (cinco) decisões, a prisão preventiva foi decretada com fundamento na garantia da ordem pública e por conveniência da instrução criminal. E em 2 (duas) decisões, a garantia da ordem pública, a conveniência da instrução criminal e a garantia da aplicação da lei penal serviram como argumento para decretação da prisão preventiva. Isoladamente, a garantia da aplicação da lei penal foi invocada como fundamento da decretação da prisão preventiva em 3 (três) decisões e a conveniência da instrução criminal em 2 (duas) das 192 (cento e noventa e duas) decisões. Tudo conforme representado na figura abaixo. 
REIS JÚNIOR, Almir Santos; OLIVEIRA, Gisele Mara de. Um olhar sombrio da justiça estadual criminal em

Figura 1 - Relação entre os fundamentos invocados nas decisões judiciais para decretação da prisão preventiva

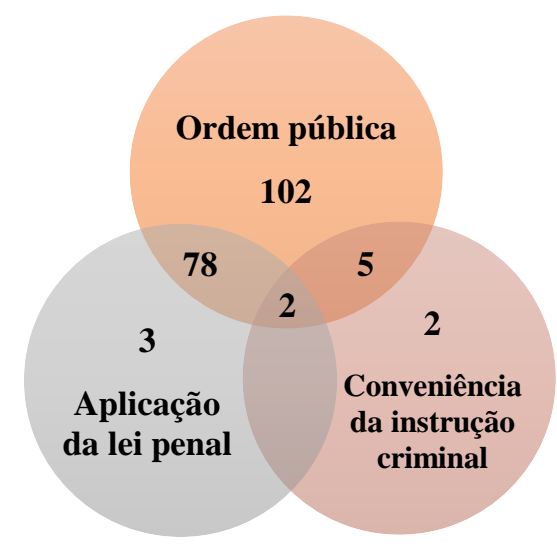

Fonte: Os autores (2019).

Nas decisões estudadas, o risco para a aplicação da lei penal se apresentou como sinônimo de possibilidade de fuga do autuado. Para afastar o perigo de comprometimento da aplicação da futura e eventual sanção penal por fuga do apenado, a prisão preventiva foi decretada porque o detido assumia condição de foragido de unidade prisional na qual cumpria pena pela prática de delito anterior em regime semiaberto; por se desconhecer o endereço e as ocupações do autuado; porque o investigado poderia fugir por medo de represálias dos demais supostos membros da associação criminosa; porque presentes prova da materialidade delitiva e indícios suficientes de autoria; e, literalmente, porque "o agente poderia se furtar à aplicação da lei penal, fugindo do domicílio da culpa", como, aliás, indicou-se na maioria das decisões judiciais assentadas na garantia da aplicação da lei penal.

A prisão para assegurar a aplicação da lei penal possui natureza tipicamente cautelar, tendo em vista o fim a que se destina, a saber, assegurar a utilidade e a eficácia de um provimento condenatório, como defendeu Badaró (2008). A despeito disso, nas decisões analisadas, os motivos declaradamente enunciados e invocados para justificar a decretação da prisão preventiva não demonstraram a existência de um perigo concreto e atual de fuga.

Por se tratar de máxima afetação ao direito de liberdade, a prisão preventiva exige o mais elevado grau de probabilidade com relação ao periculum libertatis e a demonstração concreta da base empírica idônea (CAPEZ, 2015). Nesse sentido, a decretação da prisão preventiva para a garantia da aplicação da lei penal justifica-se quando se constatar, de maneira indiscutível e a partir de elementos concretos, risco atual e efetivo de fuga do investigado ou acusado e, com isso, risco de não aplicação da lei na hipótese de sentença condenatória (LOPES JUNIOR, 2017). Não obstante, nos casos examinados, a maioria das decisões foram tomadas 
REIS JÚNIOR, Almir Santos; OLIVEIRA, Gisele Mara de. Um olhar sombrio da justiça estadual criminal em

sob o argumento de que o acusado poderia fugir do domicílio da culpa e se furtar à aplicação da lei penal sem qualquer elemento sugestivo empírico e concreto. Além disso, nenhuma decisão apontou qualquer situação que sugerisse atual e concreta tentativa de frustração da aplicação da lei penal ou de fuga do acusado.

As decisões avaliadas não revelaram as circunstâncias concretas ensejadoras do perigo atual, efetivo e real de comprometimento da execução de eventual e futura pena. A prisão preventiva foi decretada para afastar uma situação de perigo de frustração da aplicação da lei penal sem, contudo, evidenciar-se o próprio risco, maculando o art. 93, inciso IX, da Constituição Federal de 1988 e em manifesta violação ao direito fundamental à liberdade individual.

Por conveniência da instrução criminal, nas decisões estudadas, a prisão preventiva foi decretada tendo em vista que testemunhas ouvidas pela autoridade policial haviam optado por não se identificarem; pelos antecedentes criminais em conjunto com a suposta prática do delito de tráfico de drogas; e porque a prisão preventiva seria necessária para a elucidação dos fatos.

A prisão preventiva por conveniência da instrução criminal ou, mais precisamente, para a tutela da prova constitui medida tipicamente cautelar e instrumental em relação ao processo, uma vez que objetiva garantir a efetividade do processo. Dessa maneira, à luz da Constituição Federal, representa um fundamento válido para a imposição de medida restritiva da liberdade anteriormente ao trânsito em julgado de sentença penal condenatória (BADARÓ, 2008). Contudo, tal como qualquer medida cautelar, a imposição da prisão preventiva por conveniência da instrução criminal exige elementos fáticos que demonstrem, de modo concreto, o risco ao regular desenvolvimento da investigação ou da instrução provocado pela interferência do imputado na coleta de elementos de informação ou de prova (LOPES JUNIOR, 2017).

Dos pronunciamentos examinados, nenhum apontou um comportamento do próprio acusado que sugerisse efetiva interferência na colheita de elementos de informação ou na produção de provas. A opção de testemunhas por ocultar a identidade em depoimento prestado perante a autoridade policial na fase pré-processual, bem como a existência de antecedentes criminais, a prática de determinado delito e uma genérica menção à necessidade de elucidação dos fatos não constituem elementos concretos a evidenciar um comportamento de ingerência prejudicial à instrução criminal atribuível ao investigado, muito menos a ponto de se determinar a segregação cautelar. Dessa maneira, nos casos avaliados, a prisão preventiva também foi decretada por conveniência da instrução criminal sem que tivesse sido indicado qualquer fundamento idôneo, em indiscutível violação à presunção constitucional de inocência e ao direito fundamental à liberdade individual. 
REIS JÚNIOR, Almir Santos; OLIVEIRA, Gisele Mara de. Um olhar sombrio da justiça estadual criminal em

Os argumentos empregados nas decisões até então examinadas, apesar de sugerirem o que Rodrigo Capez (2015) considerou como erro no processo de justificação, por falha na identificação do periculum libertatis, importaram na prisão preventiva dos flagranteados. Pelas mais diversas, precárias e abstratas razões, os magistrados julgaram que seria mais adequado inserir os acusados em um sistema carcerário notoriamente caracterizado pela violação generalizada e sistêmica de direitos fundamentais e da própria dignidade humana, conforme retratado por Wermuth e Assis (2017), do que deixar que respondessem ao processo em liberdade. As decisões analisadas sinalizam desconsideração do indivíduo submetido ao processo como sujeito de direito, em atendimento, por outro lado, à demanda por mais controle e rigor penal, em alinhamento ao discurso punitivista (PAIVA, 2014).

No que concerne à prisão preventiva como garantia da ordem pública, o fundamento nitidamente preferido pelos julgadores assumiu diversos contornos.

Em regra, a subsunção do fato à própria descrição abstrata dos elementos que integram a estrutura de um tipo penal e a própria pena cominada ao delito conduziram à decretação da prisão preventiva para assegurar a ordem pública. A pena abstratamente imposta ao delito assumiu também a qualidade de fundamento, apesar de, legalmente, constituir apenas condição para a decretação da prisão preventiva, conforme enunciado no art. 313, inciso I, do Código de Processo Penal. Nas decisões examinadas, a ordem pública se apresentou como sinônimo de credibilidade da Justiça; de clamor público; de meio social; de tranquilidade da sociedade; de integridade da vítima; e de segurança. As decisões não revelaram um perigo atual, concreto e efetivo ao desenvolvimento da investigação ou do processo.

A prisão preventiva foi declaradamente decretada como uma resposta punitiva imediata do Poder Judiciário em atendimento ao anseio da sociedade por segurança e pelo combate e punição da prática de infrações penais, especialmente de delitos graves, assim considerados os punidos com pena máxima superior a 4 (quatro) anos, o tráfico de drogas, a associação para o tráfico de drogas, o homicídio qualificado, o roubo majorado, a infração penal praticada com emprego de violência doméstica e familiar, o delito praticado com disparo de arma de fogo ou com emprego de arma branca ou cometido com violência real ou grave ameaça, os crimes hediondos, o delito que expõe a vítima a risco grave, o delito patrimonial praticado com invasão do domicílio da vítima, os delitos patrimoniais e o delito praticado em desrespeito a medidas protetivas de urgência.

A prisão preventiva também foi expressamente decretada para retirar do meio social um indivíduo considerado "perigoso", de personalidade inclinada para a prática de infrações penais e dedicado às atividades criminosas e, com isso, manter a integridade da vítima, a tranquilidade 
e a segurança da comunidade e desestimular a prática de infrações penais. Nesses casos, a periculosidade do detido derivou da reincidência; da existência de antecedentes criminais; da existência de processo penal instaurado anteriormente para apurar a prática do mesmo tipo penal; da recente passagem do autuado por audiência de custódia; da suposta prática de tráfico de drogas e associação para o tráfico de drogas. Também foram considerados perigosos os detidos que estavam cumprindo pena pela prática de delito anterior e os autuados que se encontravam submetidos à medida cautelar diversa da prisão imposta em outro processo.

Nos casos examinados, a prisão preventiva como garantia da ordem pública não possuiu qualquer relação com a investigação criminal ou com o processo penal. Em nome da garantia da ordem pública, a medida de privação da liberdade individual foi imposta como uma medida de controle social, de prevenção e de retribuição imediata da resposta penal.

Do ponto de vista teleológico, a prisão preventiva para garantia da ordem pública demonstrou possuir natureza de tutela antecipada, na medida em que buscou antecipar a privação da liberdade individual como efeito prático da condenação penal e não pretendeu conservar uma situação necessária para assegurar o desenvolvimento do processo e a utilidade ou a eficácia de um futuro provimento condenatório. Desvinculada da natureza cautelar, as prisões preventivas como garantia da ordem pública não podem ser consideradas compatíveis com a presunção constitucional de inocência, e, portanto, figuram como ilegítimas e ilegais (BADARÓ, 2008).

Mais do que isso, nos casos examinados, a prisão preventiva para garantia da ordem pública assumiu forma de medida de proteção e defesa de uma ordem social. O juízo de necessidade da providência, a função tipicamente cautelar da medida e os direitos fundamentais dos autuados foram postos em segundo plano.

A prisão preventiva enquanto medida cautelar foi readequada como um instituto declaradamente promotor da segurança pública, com vistas a atender à demanda da sociedade, para quem, mesmo sem correspondência com a realidade, o encarceramento simboliza a severidade do sistema penal e o controle da criminalidade, conforme apontam Pessoa e Lima (2019). Nesse sentido, a prisão preventiva para garantia da ordem pública se alinhou à ideologia da punição segundo a qual o encarceramento em massa proporciona à sociedade uma ilusória eficácia punitiva, como defende Vasconcellos (2008). Considerando que a expressiva maioria das decisões examinadas foram embasadas na garantia da ordem pública, em detrimento da natureza e finalidade tipicamente cautelar da medida, revelou-se a predominância de um discurso que desconsidera a presunção de inocência e que se alinha ao punitivismo (VASCONCELLOS, 2008). 
Prosseguindo com a análise do conteúdo das decisões, também houve indicação dos motivos pelos quais a prisão preventiva não poderia ser substituída por providências cautelares diversas. Quando não limitadas a "porque são insuficientes e inadequadas" ou "porque são impertinentes e ineficazes", as razões declaradas que impediram a substituição da prisão por outra cautelar foram a insuficiência das medidas cautelares diversas da prisão para resguardar o direito, para evitar a prática de novas infrações penais, para garantir a ordem pública ou para assegurar a aplicação da lei penal e a condição de reincidente do detido. Também serviram como obstáculo à substituição da prisão preventiva por cautelar diversa a recente passagem do autuado por audiência de custódia; a existência de recente condenação pela prática do mesmo tipo penal; a existência de processo penal instaurado em desfavor do detido para apurar a prática de infração penal semelhante; a suposta prática de infração penal durante período de submissão à medida cautelar diversa da prisão imposta em outro processo; e a infração penal e as respectivas circunstâncias (como delito praticado com disparo de arma de fogo, furto qualificado, tráfico de drogas e associação para o tráfico de drogas, quantidade de droga apreendida, homicídio qualificado, roubo e roubo qualificado, ameaça e porte de arma com numeração suprimida e estupro).

Nesse sentido, as mesmas razões que justificaram a admissibilidade da prisão preventiva motivaram igualmente a inadmissibilidade das medidas cautelares diversas. Então, as decisões não consideraram satisfatoriamente a possibilidade de aplicação das medidas cautelares diversas da prisão em substituição à prisão preventiva.

Ainda, em diversos casos nos quais a prisão em flagrante delito havia sido convertida em prisão preventiva, a medida cautelar representou maior afetação à liberdade individual do que a própria pena aplicada, em violação ao princípio da proporcionalidade que governa as medidas cautelares (BADARÓ, 2008). Em 29 (vinte e nove) das 53 (cinquenta e três) sentenças condenatórias que já haviam sido proferidas ao tempo do estudo, a pena privativa de liberdade imposta foi inferior ou igual a 4 (quatro) anos, o que, em regra, admite o cumprimento da sanção penal em regime inicial aberto, conforme o disposto no art. $33, \S 2^{\circ}$, alínea "c", do Código Penal e quiçá a substituição da pena privativa por restritivas de direitos, nos termos do art. 44 do Código Penal. Nesses casos, a prisão preventiva decretada foi desproporcional ao resultado final do processo, cujo prognóstico deve o julgador realizar, conforme lecionou Badaró (2008).

Em resumo, de acordo com as decisões examinadas, a prisão preventiva, assim como as demais medidas cautelares, não tem sido imposta com observância da natureza cautelar, da finalidade processual, da excepcionalidade e dos fundamentos previstos no Código de Processo Penal e delineados no plano teórico. A expressiva maioria das decisões examinadas foram 
REIS JÚNIOR, Almir Santos; OLIVEIRA, Gisele Mara de. Um olhar sombrio da justiça estadual criminal em

conduzidas por um discurso punitivista e foram calcadas na presunção de uma situação de perigo, na presunção de culpabilidade, na presunção de periculosidade, na presunção de insuficiência e inadequação das medidas cautelares diversas. O emprego de argumentos abstratos e de discursos marcados pela declarada necessidade de legitimação da atividade judicial, bem como pela ideia de encarceramento preventivo como meio de proteção social nas decisões estudadas revela que a prisão preventiva tem representado uma verdadeira providência de controle social e de punição imediata, em total descompasso com a natureza cautelar da medida.

\section{Considerações finais}

O estudo foi desenvolvido com o objetivo de compreender se as razões invocadas nas decisões de decretação da prisão preventiva proferidas pelos Juízes de Direito do Foro Central da Comarca da Região Metropolitana de Maringá, Estado do Paraná, alinham-se à natureza, à finalidade, aos princípios e aos fundamentos que demarcam a medida cautelar.

Nesse caminho, entendeu-se que a prisão preventiva constitui uma medida cautelar do processo penal que tem por finalidade assegurar o regular desenvolvimento da investigação criminal ou do processo penal por meio do afastamento de um perigo concreto e efetivo decorrente do estado de liberdade do investigado ou acusado quando as medidas cautelares alternativas à prisão se revelarem insuficientes para o afastamento do risco e inadequadas à gravidade do delito, às circunstâncias do fato e às condições pessoais do autuado.

Compreendeu-se, também, que a decretação da prisão preventiva se condiciona à manifestação concomitante de ao menos uma das hipóteses previstas no art. 313 do Código de Processo Penal, do fumus comissi delicti e do periculum libertatis, ambos descritos no art. 312 do Código de Processo Penal.

Analisou-se 320 (trezentos e vinte) decisões proferidas por Juízes de Direito do Foro Central da Comarca da Região Metropolitana de Maringá, Estado do Paraná, por meio das quais se deliberou sobre a necessidade de imposição de medida cautelar no contexto de recebimento de autos das prisões em flagrante delito registradas nos meses de janeiro e junho de 2018.

Da análise da amostra coletada, constatou-se que 192 (cento e noventa e duas) decisões judiciais importaram na conversão da prisão em flagrante delito em prisão preventiva e 128 (cento e vinte e oito) resultaram na concessão de liberdade provisória com imposição de medidas cautelares alternativas à prisão. Então, ou se decretou a prisão preventiva ou se impôs providência cautelar alternativa à prisão ao detido. 
REIS JÚNIOR, Almir Santos; OLIVEIRA, Gisele Mara de. Um olhar sombrio da justiça estadual criminal em

Identificou-se que as decisões de concessão de liberdade provisória com imposição de medidas cautelares alternativas à prisão não apresentaram fundamentação e importaram excesso de intervenção nos direitos individuais do autuado.

Observou-se que a maioria das decisões de decretação da prisão preventiva se assentou na garantia da ordem pública, mas que, independentemente da razão invocada, não apresentou satisfatoriamente o fundamento (periculum libertatis) indispensável para a imposição da medida.

Todas as decisões examinadas importaram na submissão do detido à medida cautelar e nenhuma revelou o perigo atual, concreto e efetivo ao desenvolvimento da investigação ou do processo atribuível ao estado de liberdade do detido que ensejasse e legitimasse a imposição da medida.

Diante de tudo, conclui-se que as medidas cautelares na Justiça Estadual em Maringá, no Paraná, sobretudo a prisão preventiva, não têm sido impostas com observância da natureza acautelatória, da finalidade processual, da excepcionalidade e dos fundamentos previstos no Código de Processo Penal e delineados no plano teórico.

\section{Referências}

BADARÓ, Gustavo Henrique Righi Ivahy. A prisão preventiva e o princípio da proporcionalidade: proposta de mudanças legislativas. Revista da Faculdade de Direito, Universidade de São Paulo, v. 103, p. 381-408, jan. 2008.

BRASIL. Ata da 341a. Sessão da Assembleia Nacional Constituinte. Diário da Assembleia Nacional Constituinte, Câmara dos Deputados, Brasília, DF, 5 out. 1988, p. 14380-14382. Disponível em: <http://www2.camara.leg.br/atividadelegislativa/plenario/discursos/escrevendohistoria/25-anos-da-constituicao-de1988/constituinte-1987-1988/pdf/Ulysses\%20Guimaraes\%20-

\%20DISCURSO\%20\%20REVISADO.pdf>. Acesso em: 1 out. 2018.

CAPEZ, Rodrigo. A individualização da medida cautelar pessoal no processo penal brasileiro. 2015. Dissertação (Mestrado em Direito Processual) - Faculdade de Direito, Universidade de São Paulo, São Paulo, 2015.

CONSELHO NACIONAL DE JUSTIÇA. Cadastro nacional de presos. Disponível em: <http://www.cnj.jus.br/files/conteudo/arquivo/2018/08/57412abdb54eba909b3e1819fc4c3ef4. pdf>. Acesso em: 24 jun. 2019.

CONSELHO NACIONAL DE JUSTIÇA. Geopresídios. Disponível em:

<http://www.cnj.jus.br/inspecao_penal/mapa.php>. Acesso em: 24 jun. 2019. 


\section{DEPARTAMENTO PENITENCIÁRIO NACIONAL. Levantamento nacional de}

informações penitenciárias. Disponível em: <https://www.justica.gov.br/news/ha-726-712pessoas-presas-no-brasil/relatorio_2016_junho.pdf>. Acesso em: 24 jun. 2019.

DEPARTAMENTO PENITENCIÁRIO NACIONAL. Levantamento nacional de informações penitenciárias: atualização junho de 2017. Disponível em:

$<$ http://depen.gov.br/DEPEN/depen/sisdepen/infopen/relatorios-sinteticos/infopen-jun-2017rev-12072019-0721.pdf>. Acesso em: 04 out. 2019.

FERNANDES, Antonio Scarance. Processo penal constitucional. 2. ed. São Paulo: Revista dos Tribunais, 2000.

GONÇALVES, Marianna Moura. Prisão e outras medidas cautelares pessoais à luz da proporcionalidade. 2011. Dissertação (Mestrado em Direito Processual) - Faculdade de Direito, Universidade de São Paulo, São Paulo, 2011.

GUSMAN, Fabio. A prisão preventiva de ofício: análise crítica à luz do sistema constitucional acusatório. 2015. Dissertação (Mestrado em Direito Processual) - Faculdade de Direito, Universidade de São Paulo, São Paulo, 2015.

LOPES JUNIOR, Aury. Prisões cautelares. 5. ed. São Paulo: Saraiva, 2017.

MENDONÇA, Andrey Borges de. Análise crítica da prisão preventiva na Lei 12.403/2011: proposta à luz de modelos estrangeiros e da Convenção Americana de Direitos Humanos. 2015. Dissertação (Mestrado em Direito Processual) - Faculdade de Direito, Universidade de São Paulo, São Paulo, 2015.

OLIVEIRA, Jorge Falcão Marques de. A implementação da audiência de custódia no Brasil e as consequências jurídicas da sua não realização. 2017. Dissertação (Mestrado em Desenvolvimento no Estado Democrático de Direito) - Faculdade de Direito de Ribeirão Preto, Universidade de São Paulo, Ribeirão Preto, 2017.

PAIVA, Luiz Guilherme Mendes de. Populismo penal no Brasil: do modernismo ao antimodernismo penal, 1984 - 1990. 2014. Doutorado. Faculdade de Direito, Universidade de São Paulo. São Paulo, 2014.

PESSOA, Sara de Araújo; LIMA, Fernanda da Silva. Racismo e política criminal: uma análise a partir do Documentário 13th $-13^{\mathrm{a}}$ Emenda. Revista Thesis Juris, São Paulo, v. 8, n. 2, p. 275-294, jul./dez. 2019.

VASCONCELLOS, Fernanda Bestetti de. A prisão preventiva como mecanismo de controle e legitimação do campo jurídico. 2008. 178 f. Dissertação (Mestrado em Ciências Sociais) - Pontifícia Universidade Católica do Rio Grande do Sul, Porto Alegre, 2008.

WERMUTH, Maiquel Ângelo Dezordi; ASSIS, Luana Rambo. A pena privativa de liberdade e seu delineamento legal nacional e internacional: descompasso com a realidade operativa do sistema carcerário brasileiro. Revista Thesis Juris, São Paulo, v. 6, n. 2, p. 280-311, maio/ago. 2017. 